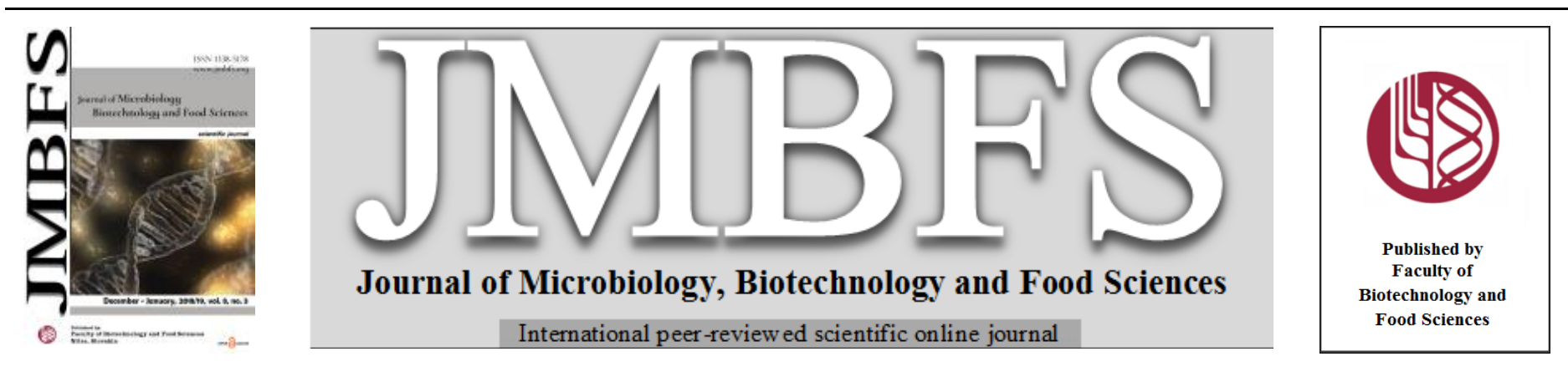

\title{
PRODUCTION OF INTERLEUKIN 1BETA AND INTERFERON GAMMA BY BOVINE MAMMARY GLAND LEUKOCYTES STIMULATED BY LIPOPOLYSACCHARIDE
}

\author{
Eliska Kabourkova, Matej Mika, Ales Pavlik, Petr Slama*
}

Address(es): Ing. Petr Slama, Ph.D.,

Mendel University in Brno, Faculty of AgriSciences, Department of Animal Morphology, Physiology and Genetics, Zemdelska 1/1665, 613 00 Brno, Czech Republic, Phone: +420545133146

*Corresponding author: petr.slama@mendelu.cz

doi: $10.15414 /$ jmbfs.2018-19.8.3.882-884

\section{ARTICLE INFO}

Received 25. 5. 2018

Revised 21.9. 2018

Accepted 24. 9. 2018

Published 1. 12. 2018

Regular article

oPEN $\partial_{\text {ACCESS }}$

\begin{abstract}
The aim of this trial was to investigate the production of the pro-inflammatory cytokines interleukin 1beta (IL-1 $\beta$ ) and interferon gamma (IFN- $\gamma$ ) produced by bovine mammary gland leukocytes following lipopolysaccharide (LPS) challenge ( $5 \mu \mathrm{g}$ LPS of Escherichia coli in $20 \mathrm{ml}$ of PBS) or PBS $(20 \mathrm{ml})$ as a control. The leukocytes were obtained by mammary gland lavage 1, 2, 3, and 7 days following the stimulation. The concentration levels of these cytokines were analyzed by sandwich ELISA. Eight clinically healthy crossbred heifers (Holstein x Czech Pied) were selected for this study. The heifers were group housed in a tie-stall barn and fed a total mixed diet. Higher average number of leukocytes $(\mathrm{P}<0.01)$ was recorded for LPS than for PBS stimulation on day 1 . The production of IL-1 $\beta$ increased following the stimulation on day 1 . After that gradual decline was detected. The IFN- $\gamma$ production showed a similar trend. Positive correlation between IL-1 $\beta$ and IFN- $\gamma$ increased level was found.
\end{abstract}

Keywords: mastitis; mammary gland; interleukin 1beta; interferon gamma; lipopolysaccharide; dairy cattle

\section{INTRODUCTION}

Mastitis could be generally defined as an inflammation of mammary gland and considered as a costly and multifactorial disease. Its gravity depends on the environment, the pathogen and the host (De Vliegher et al., 2012). Mastitis are often caused by many kinds of bacteria such as Gram-positive bacteria like staphylococci (Staphylococcus aureus), coagulase-negative staphylococci (Staphylococcus chromogenes, Staphylococcus simulans, Staphylococcus epidermis), streptococcus (Streptococcus agalactiae, Streptococcus uberis, Streptococcus dysgalactiae, Streptococcus bovis), and other Gram-positive bacteria (Actinomyces pyogenes, Corynebacterium bovis, Enterococcus faecium, Enterococcus faecalis, Bacillus pumilus, Bacillus licheniformis, Mycobacterium tuberculosis). When talking about Gram-negative bacteria, mastitis could be triggered by Escherichia coli, Pasteurella, Proteus, Pseudomonas, and Serratia species (Contreras and Rodriguez, 2011). Although, there are many kinds of bacteria causing mastitis the most important originators are Staphylococcus aureus and E. coli (Sutra and Poutrel, 1994). The major pathogenic component of Staphylococcus aureus is lipoteichoic acid (LTA) occured in cell wall (Van Amersfoort et al., 2003). The main endotoxin of E. coli is lipopolysaccharide (LPS) fulfilling as a component of the outer membrane of cell wall of Gramnegative bacteria (Rietschel et al., 1994). There is an analogy between the LPS of Gram-negative bacteria and LTA of Gram-positive bacteria (Van Amersfoort et al., 2003).

Cytokines are water-soluble regulatory peptides which are produced throughout inflammation (Taniguchi, 1995). Their concentration could be elevated because of mastitis (Trinchieri, 1997). Interleukin-1 (IL-1) plays an important role in the host defense (Pruitt et al., 1995). It is also known to be one of the most effective endogenous fever inductor (Dinarello, 1998). This cytokine is produced by monocytes, lymphocytes, macrophages, dendritic cells, endothelial and epithelial cells, and fibroblasts (Barksby et al., 2007). Interferon gamma (IFN- $\gamma$ ) has multiple functions in innate and adaptive immune responses (Bao et al., 2013) and regulation of early gene expression of Th2 (Torres $\boldsymbol{e t}$ al., 2004). It is also known to be important in activation of immune responses against viruses (Presti et al., 1998).

The aim of the study was to investigate the effect of LPS on production of selected cytokines as the simulation of serious inflammation of mammary gland. Cytokine network is very complicated and new knowledge about these proteins is important to develop better system of prevention, diagnosis and therapy of mastitis.

\section{MATERIAL AND METHODS}

\section{Animal selection and trial design}

The study procedures were focused on the analysis of the inflammatory cytokines IL-1 $\beta$ and IFN- $\gamma$. The cytokine detections were determined using ELISA method. Eight clinically healthy crossbred heifers (Holstein x Czech Pied) aged 16 to 18 months were selected for this study. The heifers were group housed in a tie-stall barn and fed a total mixed diet.

The inflammatory response was conducted by LPS of E. coli, serotype 0128:B12 (Sigma, USA). The concentration used was $5 \mu \mathrm{g}$ in $20 \mathrm{ml}$ of phosphate buffered saline (PBS) per a mammary gland. PBS (Sigma, USA) was used as a control. All mammary glands were rinsed with PBS to obtain a cell suspension.

\section{Sample collection procedures}

The first sample of cells was obtained by PBS lavage of right-front quarter on day 1 , right-rear quarter on day 2 , left-front quarter on day 3 , and left-rear quarter on day 7 following LPS or PBS challenge. It was used $20 \mathrm{ml}$ of PBS for each mammary gland to stimulate and rinse them all.

The cell concentration was counted in a Bürker chamber in 20 large squares. The cells were smeared on glass slides and stained (Pappenheim). At least 200 leukocytes on each glass slide were counted to determine the differential cell count. The cytokines were determined by sandwich ELISA.

\section{ELISA}

The following kits were used to determine the cytokines: Bovine IL-1 beta Screening Set (Thermo Scientific), and Bovine IFN- $\gamma$ Screening Set (Thermo Scientific). There was used ELISA reader Sunrise (Tecan, Austria).

\section{Statistical analysis}

The total leukocyte count, differential leukocyte count and the concentration level of the cytokines were expressed as arithmetic mean (x) \pm standard deviation (SD). Data were analyzed using statistical software program STATISTICA 8.0 (StatSoft, 2007). The paired t-test was used. 


\section{RESULTS}

Total mammary gland leukocyte count

Prior to the mammary gland stimulation, the total leukocyte count obtained by the mammary gland lavage was $0.8 \pm 0.2 \times 106 / \mathrm{ml}$. The difference between the total mammary gland leukocytes count following PBS or LPS stimulation on day 1 and 2 was statistically highly significant $(P<0.01)$. The difference was not statistically significant on day 3 and 7 (figure 1).

\section{Differential cell count of mammary gland leukocytes}

The differential cell count was counted using light microscopy. At least 200 leukocytes on each glass slide were counted. The difference between using PBS or LPS as an inductor was statistically highly significant $(\mathrm{P}<0.01)$ for all kinds of leukocytes in all time points following the mammary gland stimulation (figure 2).

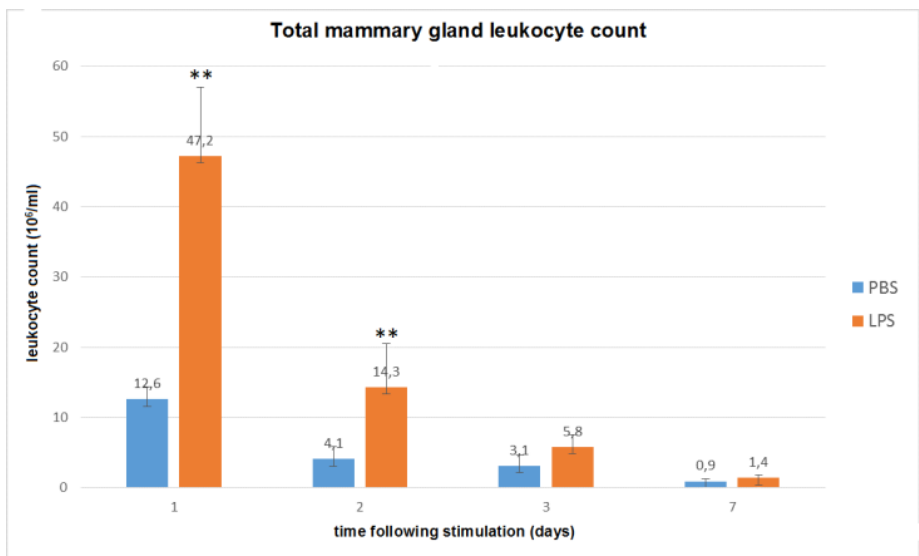

Figure 1 The total mammary gland leukocytes count

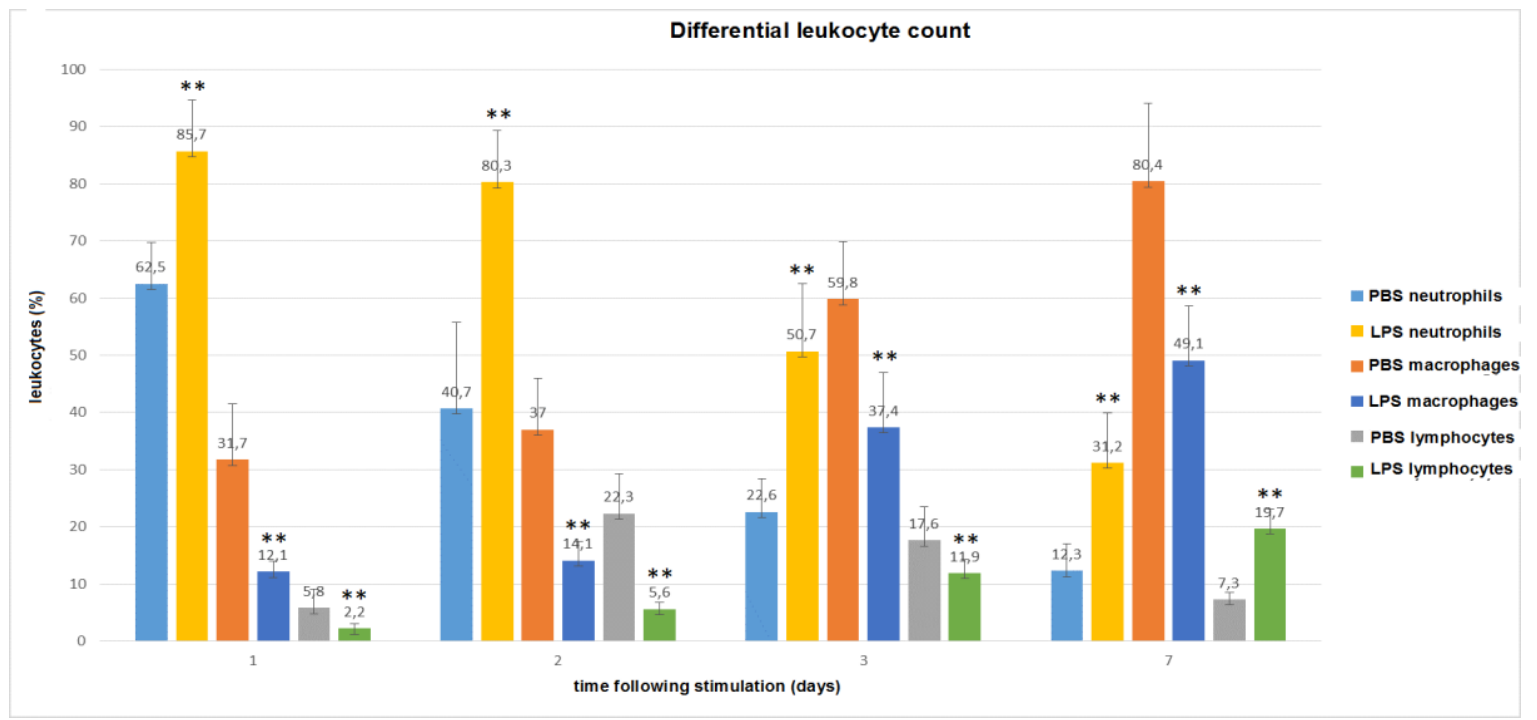

Figure 2 Differential cell count of mammary gland leukocytes

\section{Concentration level of IL-1 $\beta$}

The mammary gland leukocytes concentration level of IL-1 $\beta$ was determined following 1, 2, 3, and 7 days in vivo incubation with LPS or PBS. The difference between PBS and LPS in IL-1 $\beta$ concentration level on day 1 and 2 following the stimulation was statistically highly significant $(\mathrm{P}<0.01)$. The highly significant difference was found in all time points following the stimulation by LPS (figure $3)$.

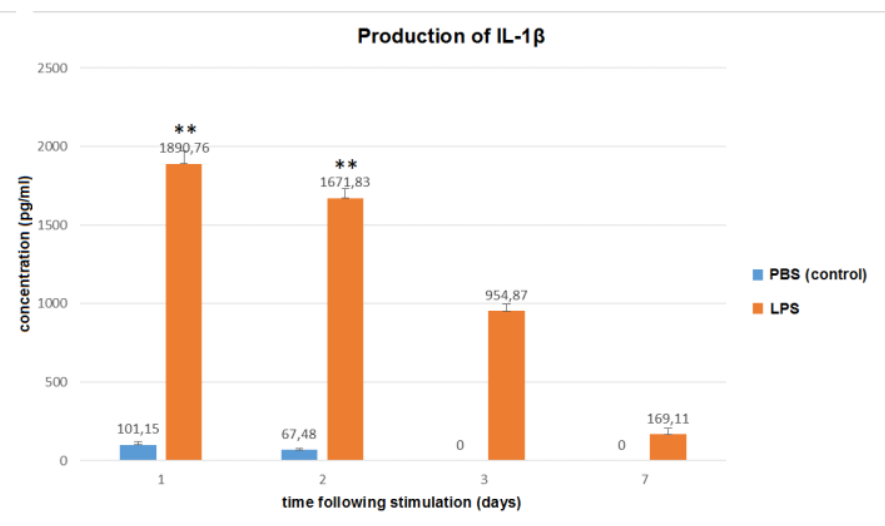

Figure 3 Mammary gland leukocytes concentration level of IL-1 $\beta$ following incubation with LPS or PBS

\section{Concentration level of IFN- $\gamma$}

The mammary gland leukocytes concentration level of IFN- $\gamma$ was determined following 1, 2, 3, and 7 days in vivo incubation with LPS or PBS. The difference between PBS and LPS in IFN- $\gamma$ concentration level on day 1 and 2 following the stimulation was statistically highly significant $(\mathrm{P}<0.01)$. The highly significant difference was found in all time points following the stimulation by LPS (figure 4).



Figure 4 Mammary gland leukocytes concentration level of IFN- $\gamma$ following incubation with LPS or PBS

\section{DISCUSSION}

The objective of this trial was to study the pro-inflammatory cytokines IL-1 $\beta$, and IFN- $\gamma$ in vivo which are produced by bovine mammary gland leukocytes.

\section{Total cell count and differential cell count of mammary gland leukocytes}

The total count of leukocytes and the differential cell count of mammary gland leukocytes obtained by lavage of the mammary gland following the mammary gland stimulation by PBS or LPS agree well with other published results (Sladek and Rysanek, 2009). In spite of Sladek and Rysanek (Sladek and Rysanek, 2009) used two times higher LPS concentration level to stimulate the mammary glands we obtained similar values of the total count and the differential cell count of mammary gland leukocytes. 


\section{Concentration level of IL-1 $\beta$}

The production of IL-1 $\beta$ was analyzed 1, 2, 3, and 7 days following the stimulation by LPS and PBS. It was higher following the stimulation by LPS than by PBS. The production of IL-1 $\beta$ started immediately following the LPS stimulation. The highest concentration was reached throughout the initiation phase of the inflammatory response. Particularly, the concentration level was $1890.76 \mathrm{pg} / \mathrm{ml}$ following 1 day stimulation. Thereafter it was dropping down. Two days after, the concentration of IL- $1 \beta$ was approximately half as it used to be at the beginning $(954.87 \mathrm{pg} / \mathrm{ml})$. The difference between the production level of IL-1 $\beta$ following the LPS or the PBS stimulation was statistically highly significant $(\mathrm{P}<0.01)$. Also Winter and Colditz (Winter and Colditz, 2002) studied the production level of IL-1 $\beta$. Staphylococcus epidermis was used as inflammatory inductor in sheep in their study. Similarly, the IL-1 $\beta$ concentration level was highest 24 hours following the mammary gland stimulation. In our previous in vitro study (Kabourkova et al., 2016), we have found production of IL-1 $\beta$ two hours from the start of incubation of mammary gland leukocytes with LPS. Studies focused on IL-1 $\beta$ are important because this cytokine may have many functions in mastitis. Xu et al. (Xu et al., 2018) referred about the effect of IL-1 $\beta$ on tight junction permeability in bovine mammary epithelial cells. IL- $1 \beta$ messenger RNA expression was induced by LPS and its enrichment is involved in multiple inflammatory signal pathways. Exogenous IL-1 $\beta$ treatment damaged the integrity of the blood-milk barrier, as indicated by the increased bovine mammary epithelial cells tight junction permeability. IL-1 $\beta$-induced increase in the bovine mammary epithelial cells tight junction permeability was mediated by the IL-1 $\beta$-ERK1/2-MLCK axis pathway. It is not clear whether IL- $1 \beta$ is also produced by Gram-positive bacteria (Kim et al., 2011).

\section{Concentration level of IFN- $\gamma$}

Similar results were found in case of the production level of both observed cytokines. The production level of IFN- $\gamma$ was higher following the stimulation by LPS than by PBS. The difference was statistically highly significant $(\mathrm{P}<0.01)$. The highest IFN- $\gamma$ level was reached 1 day following the stimulation where the concentration was $745.78 \mathrm{pg} / \mathrm{ml}$. Then it was decreasing. Two days after, the concentration of the cytokine was approximately quarter as it used to be at the beginning $(205.88 \mathrm{pg} / \mathrm{ml})$. The production level of IFN- $\gamma$ was higher for LPS than for PBS. The difference between the production level of IFN- $\gamma$ following the LPS or the PBS stimulation was statistically highly significant $(\mathrm{P}<0.01)$

Agreeably with these results, Bannerman et al. (Bannerman et al., 2004) confirmed higher IFN- $\gamma$ level throughout initial inflammation phase and then return to the original IFN- $\gamma$ values. These data correspond to the statement that IFN- $\gamma$ improves the microbicidal ativity of neutrophils by increasing of phagocytosis (Ellis and Beaman, 2004; Schroder et al., 2004) because in the initial phase of mastitis there are highest number of neutrophils which was mentioned in this study above.

\section{CONCLUSION}

In this trial, we studied the pro-inflammatory cytokines (IL-1 $\beta$, IFN- $\gamma$ ) in vivo which are produced by bovine mammary gland leukocytes. The production of IL$1 \beta$ started 1 day following the stimulation with LPS or PBS. The difference between the production level of IL-1 $\beta$ following the LPS or the PBS stimulation was statistically highly significant. The higher production of IL-1 $\beta$ was reached by LPS stimulation. The difference between the production of IFN- $\gamma$ following the stimulation by LPS or by PBS was statistically highly significant. It was higher following the stimulation by LPS than by PBS. Both cytokines showed higher concentration level following the stimulation by LPS than by PBS. Based on the fact that IL-1 $\beta$ and IFN- $\gamma$ concentration levels were elevated during the initial phase of the inflammation response, we assume both of them could be used as early stage mastitis markers. However, a cheap and fast detection method is required.

Acknowledgments: The authors wish to express their thanks to the project of IGA AF MENDELU No. AF-IGA-2018-tym002 for the financial support

\section{REFERENCES}

BANNERMAN, D.D., PAAPE, M.J., LEE, J.W., ZHAO, X., HOPE, J.C., RAINARD, P. 2004. Escherichia coli and Staphylococcus aureus elicit differential innate immune responses following intramammary infection. Clinical and Diagnostic Laboratory Immunology, 11, 463-472. http://dx.doi.org/10.1128/CDLI.11.3.463-472.2004

BAO, Y., LIU, X., HAN, C., XU, S., XIE, B., ZHANG, Q., GU, Y., HOU, J., QIAN, L., QIAN, C., HAN, H., CAO, X. 2013. Identification of IFN- $\gamma$-producing innate B cells. Cell Research, 24, 161-176. http://dx.doi.org/10.1038/cr.2013.155

BARKSBY, H.E., LEA, S.R., PRESHAW, P.M., TAYLOR, J.J. 2007. The expanding family of interleukin-1 cytokines and their role in destructive inflammatory disorders. Clinical and Experimantal Immunology, 149, 217-225. http://dx.doi.org/10.1111/j.1365-2249.2007.03441.x

CONTRERAS, G.A., RODRIGUEZ, J.M. 2011. Mastitis: comparative etiology and epidemiology. Journal of Mammary Gland Biology and Neoplasia, 16(4), 339-356. http://dx.doi.org/10.1007/s10911-011-9234-0

DE VLIEGHER, S., FOX, L.K., PIEPERS, S., MCDOUGALL, S., BARKEMA H.W. 2012. Invited review: Mastitis in dairy heifers: Nature of the disease, potential impact, prevention, and control. Journal of Dairy Science, 95,10251040. http://dx.doi.org/10.3168/jds.2010-4074

DINARELLO, C.A. 1998. Interleukin-1 beta, interleukin-18, and the interleukin1 beta converting enzyme. Annals of New York Academy of Science, 856: 1-11.

ELLIS, T. N., BEAMAN, B.L. 2004. Interferon-gamma activation of polymorphonuclear neutrophil function. Immunology, 112(1), 2-12. http://dx.doi.org/10.1111/j.1365-2567.2004.01849.x

KABOURKOVA, E., HULIKOVA, J., SLAMA, P. 2016. Production of cytokines from bovine mammary gland leukocytes influenced by bacteria infection. In PAVLIK, A. SLAMA, P., SKARPA, P. Animal Physiology 2016. Boretice, Czech Republic. pp. 93-98.

KIM, K.W., IM, J., JEON, J.H., LEE, H.G., YUN, C.H., HAN, S.H. 2011 Staphylococcus aureus induces IL-1 $\beta$ expression through the activation of MAP kinases and AP-1, CRE and NF- $\mathrm{BB}$ transcription factors in the bovine mammary gland epithelial cells. Comparative Immunology, Microbiology and Infectious Diseases, 34(4), 439-451. http://dx.doi.org/10.1016/j.cimid.2011.04.004 PRESTI, R.M., POLLOCK, J.L., DAL CANTO, A.J., O'GUIN, A.K., VIRGIN H.W. 4th. 1998. Interferon gamma regulates acute and latent murine cytomegalovirus infection and chronic disease of the great vessels. Journal of Experimental Medicine, 188, 577-588.

PRUITT, J.H., COPELAND, E.M., MOLDAWER, L.L. 1995. Interleukin-1 and interleukin-1 antagonism in sepsis, systematic inflammatory response syndrome, and septic shock. Shock, 3, 235-251.

RIETSCHEL, E.T., KIRIKAE, T., SCHADE, F.U., MAMAT, U., SCHMIDT, G., LOPPNOW, H., ULMER, A.J., ZAHRINGER, U., SEYDEL, U., DI PADOVA, F. 1994. Bacterial endotoxin: molecular relationships of structure to activity and function. FASEB Journal, 8, 217-225.

SCHRODER, K., HERTZOG, P.J., RAVASI, T., HUME, D.A. 2004. Interferongamma: An overview of signals, mechanisms and functions. Journal of Lekocyte Biology, 57, 163-189. http://dx.doi.org/10.1189/jlb.0603252

SLADEK, Z., RYSANEK, D. 2009. Expression of macrophage CD44 receptor in the course of experimental inflammatory response of bovine mammary gland induced by lipopolysaccharide and muramyl dipeptide. Research in Veterinary Science, 86: 235-240. http://dx.doi.org/10.1016/j.rvsc.2008.07.016

SUTRA, L., POUTREL, B. 1994. Virulence factors involved in the pathogenesis of bovine intramammary infections due to Staphylococcus aureus. Journal of Medical Microbiology, 40(2), 79-89.

TANIGUCHI, T. 1995. Cytokine signaling through nonreceptor protein tyrosine kinases. Science, 268, 251-255.

TORRES, K.C.L., WALDEREZ, O.D., GOLLOB, K.J. 2004. Endogenous IL-4 and IFN- $\gamma$ are essential for expression of Th2, but not Th1 cytokine message during the early differentiation of human CD4+ $\mathrm{T}$ helper cells. Human Immunology, 65(11), 1328-1335. http://dx.doi.org/10.1016/j.humimm.2004.06.007

TRINCHIERI, G. 1997. Cytokines acting on or secreted by macrophages during intracellular infection (IL-10, IL-12, IFN- $\gamma$ ). Current Opinion in Immunology, 9(1), 17-23

VAN AMERSFOORT, E.S., VAN BERKEL, T.J.C., KUIPER, J. 2003 Receptors, mediators, and mechanisms involved in bacterial sepsis and septic shock. Clinical Microbiology Reviews, 16(3), 379-414.

WINTER, P., COLDITZ, I.G. 2002. Immunological response of the lactating ovine udder following experimental challenge with Staphylococcus epidermis Veterinary Immunology and Immunopathology, 89, 57-65.

XU, T., DONG, Z., WANG, X., QI, S., LI, X., CHENG, R., LIU, X., ZHANG, Y., GAO, M.Q. 2018. IL-1beta induces increased tight junction permeability in bovine mammary epithelial cells via the IL-1beta-ERK1/2-MLCK axis upon blood-milk barrier damage. Journal of cellular biochemistry, 1-14 http://dx.doi.org/10.1002/jcb.27160 